\title{
Hereditary breast and ovarian cancer: assessment of point mutations and copy number variations in Brazilian patients
}

Felipe C Silva ${ }^{1 \dagger}$, Bianca CG Lisboa ${ }^{1 \dagger}$, Marcia CP Figueiredo ${ }^{1 \dagger}$, Giovana T Torrezan ${ }^{1}$, Érika MM Santos ${ }^{2}$, Ana C Krepischi ${ }^{1,3}$, Benedito M Rossi ${ }^{2}$, Maria I Achatz ${ }^{3,4}$ and Dirce M Carraro ${ }^{1,3^{*}}$

\begin{abstract}
Background: Germ line mutations in BRCA1 and BRCA2 (BRCA1/2) and other susceptibility genes have been identified as genetic causes of hereditary breast and ovarian cancer (HBOC). To identify the disease-causing mutations in a cohort of 120 Brazilian women fulfilling criteria for $\mathrm{HBOC}$, we carried out a comprehensive screening of BRCA1/2, TP53 R337H, CHEK2 1100delC, followed by an analysis of copy number variations in 14 additional breast cancer susceptibility genes (PTEN, ATM, NBN, RAD50, RAD51, BRIP1, PALB2, MLH1, MSH2, MSH6, TP53, CDKN2A, CDH1 and (TNNB1).
\end{abstract}

Methods: Capillary sequencing and multiplex ligation-dependent probe amplification (MLPA) were used for detecting point mutations and copy number variations (CNVs), respectively, for the BRCA1 and BRCA2 genes; capillary sequencing was used for point mutation for both variants TP53 R337H and CHEK2 1100delC, and finally array comparative genomic hybridization (array-CGH) was used for identifying CNVs in the 14 additional genes.

Results: The positive detection rate in our series was 26\%. BRCA1 pathogenic mutations were found in 20 cases, including two cases with CNVs, whereas BRCA2 mutations were found in 7 cases. We also found three patients with the TP53 R337H mutation and one patient with the CHEK2 1100delC mutation. Seven (25\%) pathogenic mutations in BRCA1/2 were firstly described, including a splice-site BRCA1 mutation for which pathogenicity was confirmed by the presence of an aberrant transcript showing the loss of the last $62 \mathrm{bp}$ of exon 7. Microdeletions of exon 4 in ATM and exon 2 in PTEN were identified in BRCA2-mutated and BRCA1/2-negative patients, respectively.

Conclusions: In summary, our results showed a high frequency of BRCA1/2 mutations and a higher prevalence of BRCA1 (64.5\%) gene. Moreover, the detection of the TP53 R337H variant in our series and the fact that this variant has a founder effect in our population prompted us to suggest that all female breast cancer patients with clinical criteria for HBOC and negative for BRCA1/2 genes should be tested for the TP53 R337H variant. Furthermore, the presence of genomic structural rearrangement resulting in CNVs in other genes that predispose breast cancer in conjunction with BRCA2 point mutations demonstrated a highly complex genetic etiology in Brazilian breast cancer families.

Keywords: Breast cancer, Mutation, BRCA1, BRCA2, HBOC, CHEK 1100delC, TP53 R337H

\footnotetext{
* Correspondence: dirce.carraro@cipe.accamargo.org.br

${ }^{\dagger}$ Equal contributors

'Laboratory of Genomics and Molecular Biology, CIPE - A. C. Camargo Cancer

Center, São Paulo, Brazil

${ }^{3}$ National Institute of Science and Technology in Oncogenomics (INCITO),

São Paulo, Brazil

Full list of author information is available at the end of the article
}

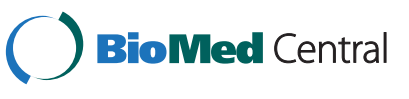

(c) 2014 Silva et al.; licensee BioMed Central Ltd. This is an Open Access article distributed under the terms of the Creative Commons Attribution License (http://creativecommons.org/licenses/by/2.0), which permits unrestricted use, distribution, and reproduction in any medium, provided the original work is properly credited. The Creative Commons Public Domain Dedication waiver (http://creativecommons.org/publicdomain/zero/1.0/) applies to the data made available in this article, unless otherwise stated. 


\section{Background}

Hereditary breast and ovarian cancer (HBOC) accounts for $5-10 \%$ of all breast cancer $(\mathrm{BC})$ cases and is inherited in an autosomal dominant fashion. Nearly $30 \%$ of HBOC patients harbor germ line point mutations or genomic structural rearrangements that result in copy number variations (CNVs) in $B R C A 1 / 2$ genes, with a lifetime risk of $45-70 \%$ for $\mathrm{BC}$ and $20-40 \%$ for ovarian cancer [1]. Mutations in these genes also confer a slightly increased risk of other types of cancer, such as pancreatic, primary peritoneal, prostate, male breast and fallopian tube cancer [2].

Germ line BRCA1 (MIM\# 113705) and BRCA2 (MIM\# $600185)$ mutations are also frequently found in isolated cases of bilateral and/or early-onset BC [3]. The frequency of these mutations is variable because a higher frequency of $B R C A 1$ mutations has been described in the United States [4], whereas a clear prevalence of $B R C A 2$ mutations has been reported in Icelandic BC families [5]. Conversely, similar mutation frequency in both genes has been described in French Canadian and British families [6,7].

Inherited mutations in other genes also influence the risk of $\mathrm{BC}$. The CHEK2 1100delC has been associated with higher $\mathrm{BC}$ risks [8], conferring a two-fold increase in $\mathrm{BC}$ risk for women and a ten-fold increase for men [8-10]. Recent studies in cancer-prone families in southeast Brazil have identified a founder germ line TP53 mutation $(\mathrm{p} \cdot \mathrm{R} 337 \mathrm{H})$ at a higher prevalence $(1: 3,000)$ than the others germ line TP53 mutations [11]. A variety of cancer types have been found in TP53 p.R337H-carrying families, such as soft tissue sarcomas, brain tumors, adrenocortical carcinomas and breast cancers [11].

Screening for mutations in the tumor suppressor genes $B R C A 1$ and BRCA2 is of great significance for breast and ovarian cancer prevention and early detection. When a mutation is identified, the cancer risk can be reduced via prophylactic mastectomy; patients can also seek effective screening strategies to detect breast cancer earlier [12]. Moreover, whether a mutation is detected, the genetic testing can be extended to relatives who can enter in specific screening programs for carriers or follow the strategy for the general population (non-carriers). More recently, emerging therapies, such as PARP inhibitors in combination with conventional treatment, have been shown to be more effective for $B R C A 1$ and $B R C A 2$ mutation carriers [13].

The complex genetic basis of hereditary breast cancer prompted us to perform a comprehensive genetic investigation of 120 Brazilian patients fulfilling clinical criteria for HBOC. We screened the BRCA1/2 genes for point mutations and CNVs. We also evaluated the presence of the CHEK2 1100delC and TP53 R337H variants via sequencing and used array comparative genomic hybridization (array-CGH) to investigate CNVs in 14 additional breast cancer-predisposing genes: PTEN, ATM, NBN, RAD50, RAD51, BRIP1, PALB2, MLH1, MSH2, MSH6, TP53, CDKN2A, CDH1 and CTNNB1.

\section{Methods \\ Patients}

One hundred twenty unrelated breast cancer patients fulfilling criteria for hereditary breast and ovarian cancer (HBOC) were recruited from 2007 to 2010 for this study. The inclusion criteria were: 1) Breast cancer diagnosed $\leq$ 45 years of age (no family history); 2) Breast cancer diagnosed $\leq 45$ years of age with 1 or more close blood relative with breast/ovarian/fallopian tube/primary peritoneal cancer at any age; 3) Breast cancer diagnosed $<45 \leq 50$ years of age with 1 or more blood relative with breast/ovarian/ fallopian tube/primary peritoneal cancer $\leq 50$ years of age; 4) Breast cancer diagnosed $>50$ of age with 1 or more blood relative with breast/ovarian/fallopian tube/primary peritoneal cancer at any age; 5) Two primary $\mathrm{BC}$ when the first occurrence was prior to age 50 ; 6) Breast cancer with a history of ovarian/ fallopian tube/primary peritoneal cancer at any age; 7) For an individual with an ethnicity that is associated with a higher mutation frequency (e.g., Ashkenazi Jewish); 8) Personal history of ovarian/fallopian tube/primary peritoneal cancer; 9) Personal history of male breast cancer. All enrolled individuals received genetic counseling and signed an informed consent. This study was performed in compliance with the Helsinki Declaration and was approved by the ethics committee of the A C Camargo Cancer Center (approval number: 870/06-B). The complete clinical and molecular information of the patients is given in the Additional file 1.

\section{Point mutation screening}

DNA from peripheral blood was purified using the Puregene Genomic DNA Isolation kit (Quiagen, Hilden, Germany) according to manufacturer's instructions. The entire coding sequence and exon-intron boundaries of the BRCA1 (U14680 or NM_007294.3) and BRCA2 (U43746 or NM_000059.1) genes were evaluated. The CHEK2 gene (NM_007194.3) and the TP53 gene (NM_000546.5) were screened solely for the c.1100delC and p.R337H mutations, respectively. All PCR products were sequenced in both forward and reverse directions on an ABI Prism 3130xl genetic analyzer (Life Technologies, Foster City, USA). Mutations were recorded and referenced with respect to the cDNA sequence using the nomenclature proposed by the BIC database [14]. PCR conditions and primer sequences are available upon request.

\section{Investigation of $B R C A 1 / 2$ CNVs by MLPA}

Patients negative for $B R C A 1 / 2$ mutations were investigated for CNVs in these genes. Exonic deletions and duplications 
affecting $B R C A 1$ and $B R C A 2$ genes were investigated on genomic DNA using the multiplex ligation-dependent probe amplification (MLPA) commercial kits P087-B1 and P045-B3 (MRC-Holland, Amsterdam, The Netherlands) according to the manufacturer's recommendations.

\section{Classification of variants}

The BIC database was searched for all BRCA1 and BRCA2 alterations [14]. Unreported mutations that generated a premature stop codon (nonsense and frameshift) were classified as pathogenic. Missense alterations classified as class 3 in the IARC_LOVD database [15] or unknown in the BIC database were considered to be variants of uncertain significance (VUSs). Variants classified as class 1 and 2 using the IARC_LOVD were considered to be wild type. In cases of inconsistency between the databases, the classification from IARC-LOVD prevailed. Additionally, the VUSs were characterized using three in silico protein prediction algorithms: SIFT [16], POLYPHEN-2 [17] and Align-GVGD [18].

\section{Transcript analysis}

For transcriptional analysis of the novel splice site variant, frozen tumor tissues were obtained from the carrier and from a sporadic breast tumor that was negative for mutations in the BRCA1 gene, which was used as a control sample. RNA samples were purified using the Precellys $24^{\circ}$ equipment (Carlsbad, California, USA), followed by total RNA extraction using an RNeasy Mini kit (Qiagen, Venlo, The Netherlands). The first strand cDNA was synthesized from $2 \mu \mathrm{g}$ of total RNA using a random hexamer primer with the Superscript first strand system for RT-PCR (Life Technologies, Foster City, USA). RT-PCR fragments of the index patient and the control sample were both obtained according to standard PCR protocols using primers adjacent to the exon involved in the splice site mutation. All RT-PCR products were inserted into the T/A plasmid vector pTZ57R/T using the InsT/Aclone PCR Product Cloning Kit (Thermo Fisher Scientific, USA), and the ligated plasmid was used for transformation in DH10B E. coli cells via electroporation $(2.5 \mathrm{KV}, 25 \mu$ FD, $200 \mathrm{OHMS}$ ), followed by single-colony sequencing on the ABI 3130xl sequencer using M13 primers.

\section{Screening of copy number alterations via array comparative genomic hybridization (array-CGH)}

Genomic CNVs affecting 14 cancer susceptibility genes (PTEN, TP53, ATM, NBN, RAD50, BRIP1, PALB2, RAD51, MLH1, MSH2, MSH6, CDKN2A, CDH1 and $C T N N B 1)$ were investigated in oligo-based array-CGH data obtained from a previous study [19]. All hybridizations were gender-matched and processed in reverse labeling duplicates; experiments were carried out using the $180 \mathrm{~K}$ whole genome platform (design 22060, Agilent
Technologies, Santa Clara, CA, USA). The Agilent Genomic Workbench software was used for the detection of CNVs (deletion and duplications) with the aberration detection method 2 (ADM-2) and a threshold of 6.7. The duplication or deletion of genomic segments were declared when one probe exhibited a $\log _{2}$ ratio of $\mathrm{Cy} 3 /$ Cy5 $>0.70$ or $<-0.70$, respectively. A careful visual inspection was performed to filter out poor quality hybridizations and noisy data. Additionally, alterations located more than $3 \mathrm{~kb}$ upstream or downstream of the coding exons were excluded. The Database of Genomic Variants (DGV-HG19, http://projects.tcag.ca/variation/) was used to exclude common variants detected in the general population. Only alterations detected in both experiments of the same patient were considered.

\section{Gene dosage qPCR}

To validate the genomic DNA CNVs, we used the quantitative duplex PCR method previously described [20]. $G A P D H$ was used as a reference gene. For array-CGH probes located in introns, PCR primers were designed to encompass the closest exon.

\section{Results}

Screening of BRCA1/2: point mutations and copy number variations; CHEK2 1100delC and TP53 R337H

The mean age of diagnosis of the first primary tumor in all 120 patients was 43 years-old (yo), with a range from 22 to 88 . Thirty-one out of 120 patients (26\%) were found to harbor pathogenic mutations, including 20 for $B R C A 1$ (64.5\%), seven for BRCA2 (22.5\%), three for TP53 R337H (10\%) and one for CHEK2 1100delC (3\%). In the BRCA1 gene, 20 patients presented 18 different mutations, of which 16 were point mutations (89\%) (Six nonsense, six frameshift, two splice site and two missense) and two were CNVs, one deletion encompassing exons 16 and 17 and a rare case of exon 24 amplification detected within $B R C A 1$ (11\%) (Table 1 and Additional file 2). The Ashkenazi Jewish mutation c.5382insC was the most recurrent and was found in three cases. The seven BRCA2 carriers presented six distinct mutations, of which three were nonsense and three were frameshift. The nonsense variant c.9709A > T was found in two cases. No CNVs were detected in BRCA2. Moreover, seven out of 28 (25\%) BRCA1/2-carriers were found to harbor novel pathogenic mutations, five in $B R C A 1$ and two in $B R C A 2$.

Interestingly, patient $\mathrm{MO}-15$ was found to harbor a germ line splice site mutation (c.560 $+2 \mathrm{~T}>\mathrm{A})$ in intron 7 of the BRCA1 gene (Figure 1A). RT-PCR products encompassing part of exon 6 to exon 8 revealed the presence of a 186-bp fragment in addition to the expected fragment of $258 \mathrm{bp}$ (Figure 1B). Sequencing of the 186-bp fragment disclosed a frameshift deletion of the last 62 bp of exon 7 due to the activation of a novel cryptic splice site within 
Table 1 Clinical and molecular description of the BRCA1, BRCA2, CHEK2 1100delC and TP53 R337H mutation carriers

\begin{tabular}{|c|c|c|c|c|c|c|c|c|}
\hline Proband & Age of onset & Tumor & Clinical criteria & Gene & Alteration & Mutation type & Exon & Reference \\
\hline SM-01 & 39 & Breast & $\mathrm{HBOC}$ & $B R C A 1$ & c.5203delTT & Frameshift & 18 & $\mathrm{BIC}$ \\
\hline SM-17 & $49 / 51$ & Ovarian/Breast & $\mathrm{HBOC}$ & $B R C A 1$ & c.3376 T > G; p.L1086X & Nonsense & 11 & $\mathrm{BIC}$ \\
\hline SM-25 & 69 & Breast & $\mathrm{HBOC}$ & $B R C A 1$ & c.120A > G; p.M1V & Missense & 2 & $\mathrm{BIC}$ \\
\hline SM-69 & 33 & Breast & $\mathrm{HBOC}$ & $B R C A 1$ & c. $5242 C>$ A; p.A1708E & Missense & 18 & $\mathrm{BIC}$ \\
\hline SM-74 & 50 & Hemangioblastoma & $\mathrm{HBOC}$ & $B R C A 1$ & c.2080delA & Frameshift & 11 & $\mathrm{BIC}$ \\
\hline MO-07 & 34 & Breast & $\mathrm{HBOC}$ & $B R C A 1$ & c.5382insC & Frameshift & 20 & $\mathrm{BIC}$ \\
\hline MO-09 & 42 & Breast & $\mathrm{HBOC}$ & $B R C A 1$ & c.5382insC & Frameshift & 20 & $\mathrm{BIC}$ \\
\hline MO-45 & 48 & Breast & $\mathrm{HBOC}$ & $B R C A 1$ & c.5382insC & Frameshift & 20 & $\mathrm{BIC}$ \\
\hline MO-13 & $32 / 44$ & Breast/Skin & $\mathrm{HBOC}$ & $B R C A 1$ & c.4831del5 & Frameshift & 16 & $\mathrm{BIC}$ \\
\hline MO-26 & 37 & Breast & $\mathrm{HBOC}$ & $B R C A 1$ & c.1499insA & Frameshift & 11 & $\mathrm{BIC}$ \\
\hline MO-31 & $38 / 63$ & Breast/Peritoneal & $\mathrm{HBOC}$ & $B R C A 1$ & c.5563G > A; p.W1815X & Nonsense & 23 & $\mathrm{BIC}$ \\
\hline MO-37 & $(-)$ & Breast & $\mathrm{HBOC}$ & $B R C A 1$ & c.3759G > T; p.E1214X & Nonsense & 11 & $\mathrm{BIC}$ \\
\hline MO-38 & $42 / 44$ & Breast/Breast & $\mathrm{HBOC}$ & $B R C A 1$ & c.307 T > A; p.L63X & Nonsense & 5 & $\mathrm{BIC}$ \\
\hline SM-50 & $36 / 47$ & Breast/Breast & $\mathrm{HBOC}$ & $B R C A 1$ & c. $4794+1 G>A$ & Splice site & 15 & $\mathrm{BIC}$ \\
\hline SM-80 & $42 / 48$ & Breast/Ovarian & $\mathrm{HBOC}$ & $B R C A 1$ & c.1446 A > T; p.K443X & Nonsense & 11 & Current study \\
\hline SM-81 & 55 & Fallopian Tube & $\mathrm{HBOC}$ & $B R C A 1$ & c.5582insT & Frameshift & 23 & Current study \\
\hline SM-89 & 40 & Breast & $\mathrm{HBOC}$ & $B R C A 1$ & c.4406 C > A; p.Y1429X & Nonsense & 13 & Current study \\
\hline MO-15 & $43 / 56$ & Breast/Ovarian & $\mathrm{HBOC}$ & $B R C A 1$ & $c .560+2 \mathrm{~T}>\mathrm{A}$ & Splice site & 7 & Carraro et al. [28] \\
\hline M0-28 & 48 & Breast & $\mathrm{HBOC}$ & $B R C A 1$ & Exon 24 amplification & LGR & 24 & Current study \\
\hline SM-03 & $36 / 36$ & Breast/Ovarian & $\mathrm{HBOC}$ & $B R C A 1$ & Exon 16-17 deletion & LGR & $16-17$ & $\mathrm{BIC}$ \\
\hline SM-08 & 33 & Breast & $\mathrm{HBOC}$ & $B R C A 2$ & c.6174delT & Frameshift & 11 & $\mathrm{BIC}$ \\
\hline SM-46 & 32 & Breast & $\mathrm{HBOC}$ & $B R C A 2$ & c.9709 A > T; p.K3161X & Nonsense & 25 & $\mathrm{BIC}$ \\
\hline SM-61 & 51 & Breast & $\mathrm{HBOC}$ & $B R C A 2$ & c.9709A > T; p.K3161X & Nonsense & 25 & $\mathrm{BIC}$ \\
\hline SM-104 & 32 & Breast & $\mathrm{HBOC}$ & $B R C A 2$ & c.3034del4 & Frameshift & 11 & $\mathrm{BIC}$ \\
\hline MO-02 & $53 / 63$ & Breast/Breast & $\mathrm{HBOC}$ & $B R C A 2$ & c.9610C > T, p.R3128X & Nonsense & 25 & $\mathrm{BIC}$ \\
\hline SM-53 & $30 / 49$ & Breast/Thyroid & $\mathrm{HBOC}$ & $B R C A 2$ & c.6242del4 & Frameshift & 11 & Current study \\
\hline SM-84 & 35 & Breast & $\mathrm{HBOC}$ & $B R C A 2$ & c.8423 T > G; p.L2732X & Nonsense & 18 & Current study \\
\hline MO-41 & 47 & Breast & $\mathrm{HBOC}$ & CHEK2 & c.1100delC; p.Thr367MetfsX15 & Frameshift & 10 & $\mathrm{BIC}$ \\
\hline SM-31 & 49 & Breast & $\mathrm{HBOC}$ & TP53 & c.1010G > A; p.R337H & Missense & 10 & IARC TP53 \\
\hline SM-31 & 49 & Breast & $\mathrm{HBOC}$ & TP53 & c.1010G > A; p.R337H & Missense & 10 & IARC TP53 \\
\hline SM-82 & 29 & Breast & $\mathrm{HBOC}$ & TP53 & c.1010G > A; p.R337H & Missense & 10 & IARC TP53 \\
\hline
\end{tabular}

(-) Not available; LGR: Large Genomic Rearrangement; BIC: Breast cancer information core database; IARC TP53: IARC TP53 database.

exon 7 (Figure 1C). Figure 1D shows the schematic representation of the premature stop codon created in the mRNA after the deletion of 62 bp of exon 7 (r. [=, 499_560del); p.Ser127Thrfs*11) caused by the germ line splice site mutation c. $560+2 \mathrm{~T}>\mathrm{A}$. The predicted protein from the aberrant mRNA apparently created an isoform of 137aa (Figure 1E).

Nineteen out of 120 HBOC patients (16\%) harbored VUSs according to our criteria (based on BIC and/or IARC-LOVD databases - see the Methods section). Among the VUS carriers, 17 variants were distinct, and two of them were described for the first time (Table 2). The VUS evaluation using the three protein prediction algorithms (PolyPhen, SIFT and GVGD-Align) showed that six were classified as likely pathogenic by at least one algorithm (three in one algorithm, two in two algorithms and one in all three algorithms). The schematic representation of all VUSs in the BRCA1 and BRCA2 genes and their functional domains on the protein are shown in Figure 2.

\section{Mutation frequency by inclusion criteria}

Overall, the mutation detection rate was $26 \%$; however, when selecting according to age of cancer onset, young women ( $\leq 35$ yo) had the highest rate at 35\% (Figure 3 ). Regarding specific $\mathrm{HBOC}$ criteria fulfilled by each family, the majority of mutation carriers $(45 \%)$ met criterion 2 (Breast cancer diagnosed $\leq 45$ yo and familial history positive for $B C$ ). Four out of five patients fulfilling the 


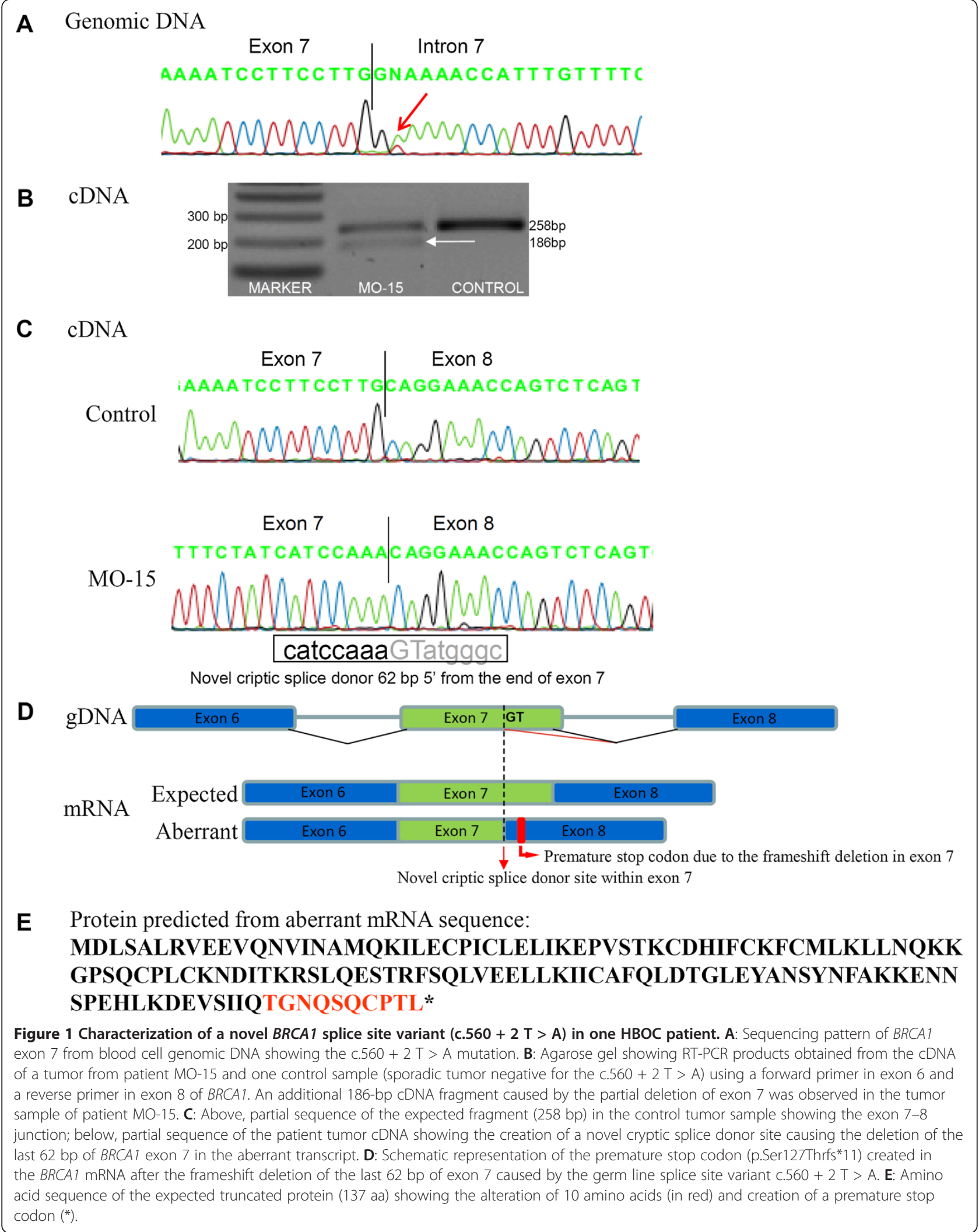


Table 2 Variants of uncertain significance (VUSs)

\begin{tabular}{ccccccccc}
\hline Variant & $\begin{array}{c}\text { No. of families } \\
\text { carrying VUS }\end{array}$ & $\begin{array}{c}\text { Co-occurrence with } \\
\text { pathogenic mutation }\end{array}$ & Gene & BIC & \multicolumn{3}{c}{ In silico analysis } & IARC-LOVD \\
\cline { 5 - 7 } database
\end{tabular}

Align GVGD: C0 (Less likely to interfere in protein function), C15, C25, C35, C45, C55, C65 (More likely to interfere in protein function); Polyphen: Variant Benign, Possibly damaging and Probably damaging; SIFT: Variant Tolerated (benign) or Affect protein function. LOVD-IARC: class 1 (Not pathogenic or of no clinical significance), class 2 (Likely not pathogenic or of little clinical), class 3 (Uncertain), class 4 (Likely pathogenic), class 5 (definitely pathogenic).

criterion for Ashkenazi Jewish ancestry (criterion 7) harbored pathogenic mutations, and patients fulfilling criterion 6 showed a detection rate of 44\% (4/9). Patients younger than 45 yo without a family history of cancer (criterion 1) did not present pathogenic mutations in our cohort (Table 3).

\section{Array CGH and gene dosage qPCR}

Among the 120 cancer patients included in this study, 100 had array CGH data available from a previous study [19], which were used for detecting CNVs within the 14 breast cancer susceptibility genes. After a careful visual inspection, two of them were found to harbor CNVs in

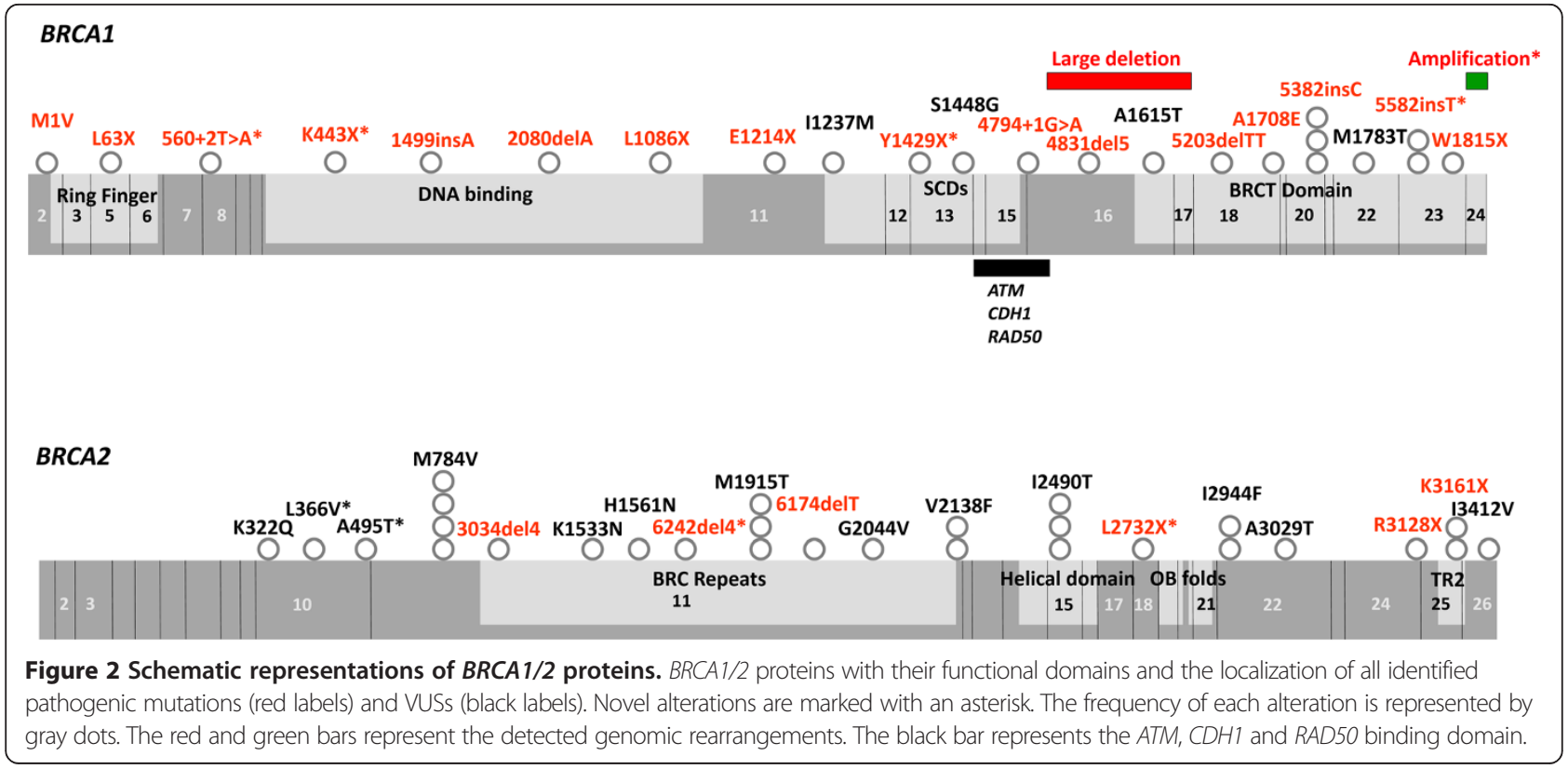




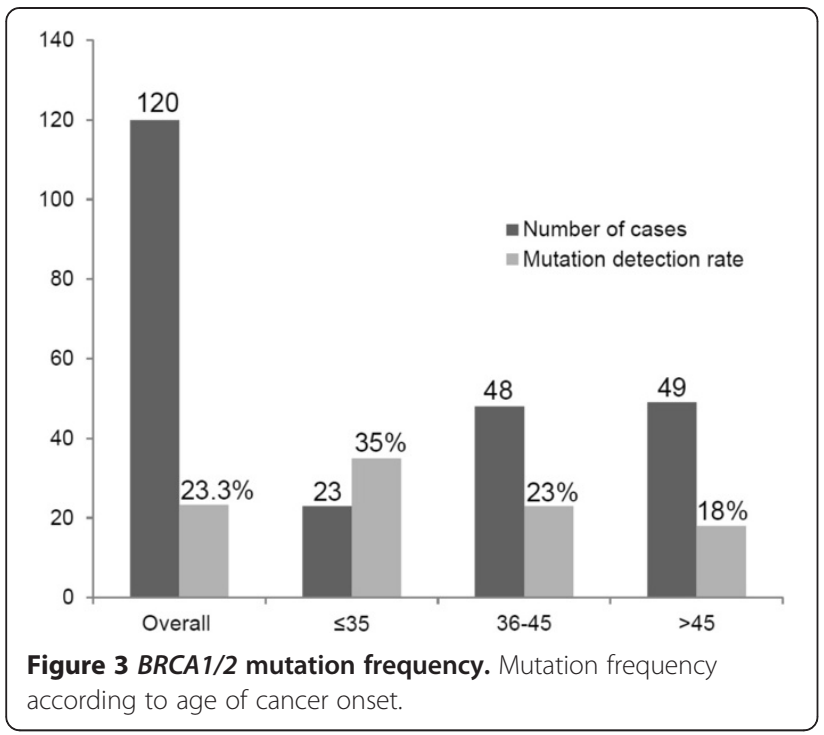

PTEN and ATM genes. The exon-4 heterozygous deletion in the ATM gene (Patient SM-46, carrier of a pathogenic BRCA2 mutation, c.K3161*) and exon-2 heterozygous deletion in the PTEN gene (Patient SM-62) were confirmed using the duplex qPCR gene dosage method (Figure 4). However, both the array CGH probe and gene dosage PCR primers for the PTEN gene were located in the deleted region that has recently been described as a polymorphic chromosomal deletion [21].

\section{Discussion}

In Brazil, data concerning the prevalence of BRCA1/2 mutations are limited. Previous studies using different selection criteria have reported mutation frequencies ranging from $2.3 \%$ to $20 \%$ [22-28]. The largest study conducted in Brazil used the protein truncation test (PTT) to evaluate $612 \mathrm{BC}$ cases with high and medium risks of breast cancer and found a mutation carrier prevalence of $3.4 \%$ [25]. In the current study, we detected a germ line mutation prevalence of $26 \%$ within the BRCA1/2 genes, TP53 R337H and CHEK2 1100delC in 120 Brazilian patients with clinical criteria for HBOC (16.5\% in BRCA1, 6\% in BRCA2, 2.5\% in TP53 and 1\% in CHEK2). Previous studies have described a mutation detection rate ranging from 8.9 to $43.8 \%$ [29-31] in $B R C A 1 / 2$, revealing differences between our cohort and others. Thus, it is important to note that our study was based on an institutional registry and probably does not represent the broad ethnic and socio-economic diversity of the Brazilian population. This can partially explain some inconsistency between different Brazilian studies, in addition to the different screening methods and inclusion criteria for selecting patients.

Regardless of specific populations and ethnic groups, recurrent $B R C A 1 / 2$ mutations are rarely detected in hereditary breast cancer. In this sense, a wide range of pathogenic mutations was detected in this series, which is expected for an unrelated cohort of an ethnically mixed population such as that of Brazil. The most frequent mutation identified in this series was the Ashkenazi Jewish 5382insC variant, which was found in approximately $10 \%$ of the mutation carriers. This is one of the most common BRCA1 mutations identified worldwide and is found both among Ashkenazi Jews and women of Slavic origin $[32,33]$.

Splice-site mutations in the BRCA1 gene are considered to be rare, and thus far, only a few splice-site mutations have been reported in the BIC database. Using transcriptional analysis of the $\mathrm{BC}$ tumor harboring the novel mutation c. $560+2 \mathrm{~T}>\mathrm{A}$, we confirmed the presence of an aberrant transcript that was not found in the control sample. Interestingly, this variant was also reported in another series of unrelated young Brazilian patients with a positive family history recently reported by us [28]. Although we were able to show that the mutant allele can

Table 3 Mutation detection rate according to inclusion criteria

\begin{tabular}{|c|c|c|c|}
\hline Hereditary Breast and Ovarian Cancer (HBOC) & Distribution by criterion & Number of mutation carriers & Positive detection rate \\
\hline 1. $\mathrm{BC} \leq 45$ years of age (no family history) & 11 & 0 & $0 \%$ \\
\hline $\begin{array}{l}\text { 2. } \mathrm{BC} \leq 45 \text { years of age with } \geq 1 \text { relative with } \mathrm{BC}, \mathrm{OC} \text {, } \\
\text { FTC and PPC at any age }\end{array}$ & 42 & 14 & $33 \%$ \\
\hline $\begin{array}{l}\text { 3. } \mathrm{BC}<45 \leq 50 \text { years of age with } \geq 1 \text { relative with } \\
\mathrm{BC}, \mathrm{OC}, \mathrm{FTC} \text { and } \mathrm{PPC} \leq 50 \text { years of age }\end{array}$ & 16 & 2 & $12 \%$ \\
\hline $\begin{array}{l}\text { 4. } \mathrm{BC}>50 \text { years of age with } \geq 1 \text { relatives with } \\
B C, O C, F T C \text { and } P P C \text { at any age }\end{array}$ & 28 & 5 & $18 \%$ \\
\hline 5. Two $B C$ when the first occurrence was prior to age 50 & 5 & 1 & $20 \%$ \\
\hline 6. BC at any age plus OC, FTC and PPC at any age & 9 & 4 & $44 \%$ \\
\hline 7. Ashkenazi Jewish ancestry & 5 & 4 & $80 \%$ \\
\hline 8. OC, FTC and PPC at any age & 3 & 1 & $33 \%$ \\
\hline 9. Male BC & 1 & 0 & $0 \%$ \\
\hline
\end{tabular}

BC: Breast cancer; OC: ovarian cancer; FTC: Fallopian tube cancer; PPC: Primary peritoneal cancer. 


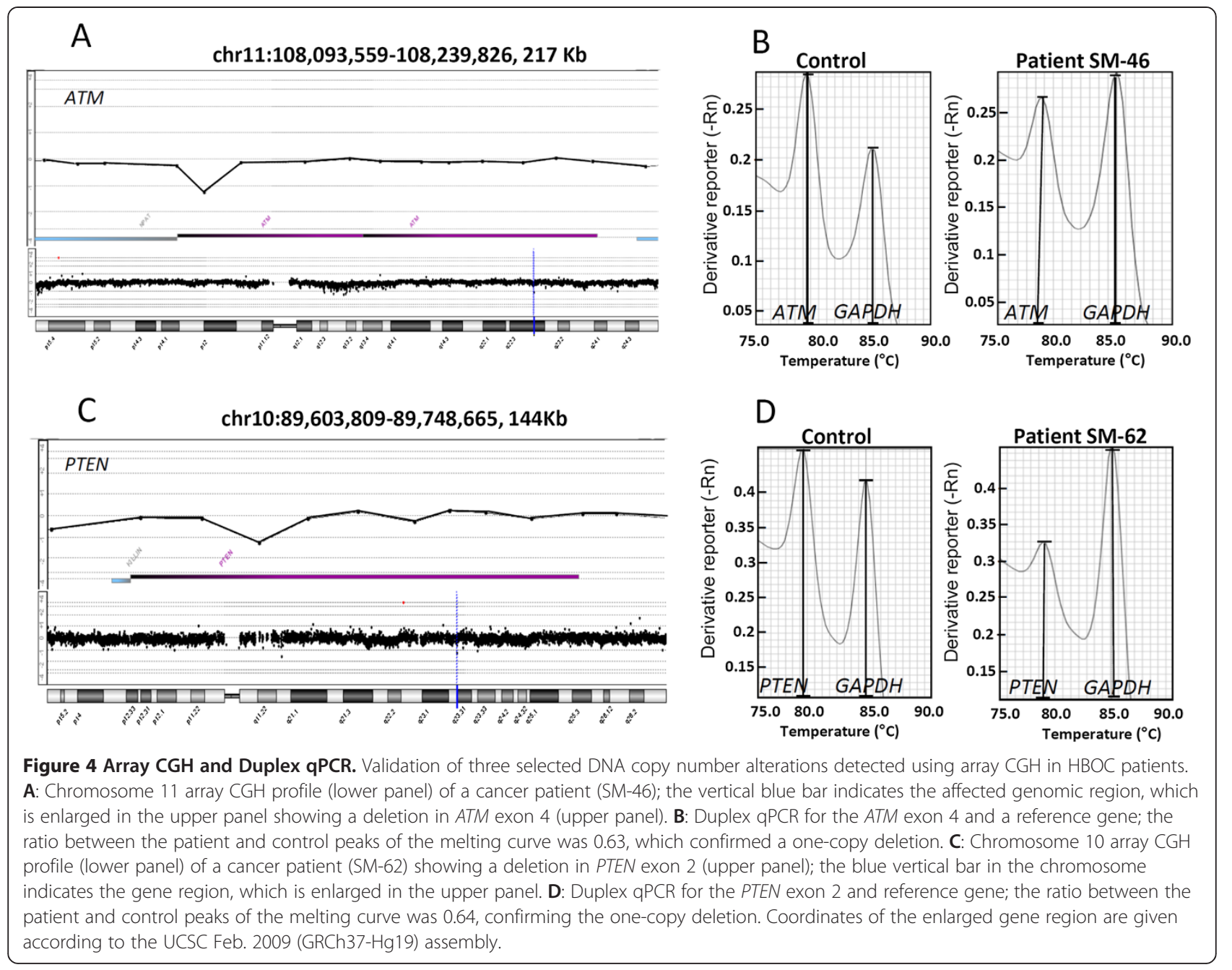

produce the aberrant transcript but not able to demonstrate whether the mutant allele was still able to produce the full-length BRCA1 transcript, this splice site was considered pathogenic because it has been reported that mutations in the highly conserved acceptor or donor sites are pathogenic per se [34].

One of the main issues in the molecular diagnosis of $B R C A 1 / 2$ mutations is the effect of VUSs in protein function. Several approaches have been used to determine the pathogenicity of VUSs, including the investigation of co-segregation within pedigrees, frequency in healthy controls, lack of co-occurrence with pathogenic mutations, and in silico analysis such as amino acid conservation and the severity of amino acid change [35]. According to the criteria adopted in this study, only the p.M784V variant had an uncertain clinical relevance according to the IARC-LOVD database; however, because of the lack of co-segregation in one affected sister and the presence of the variant in a set of 95 healthy individuals (data not shown), this variant is likely to have little or no clinical relevance.
Our results demonstrated that the age at cancer diagnosis had a significant impact on the positive detection rate. In this sense, we found that the group of earlyonset breast cancer patients ( $\leq 35$ yo) is at a higher risk of carrying pathogenic mutations in the $B R C A 1 / 2$ genes with a positive detection rate of $35 \%$, which reached $42 \%$ in cases with a family history of breast cancer (not shown). In a previous study by our group, patients $\leq 35$ years of age showed a mutation rate of $20 \%$ in $B R C A 1 / 2$ genes with a significant increase of the detection rate in young women with a positive family history (37.5\%) [28]. The concordance among these studies in early-onset breast cancer patients strengthens the hypothesis that young Brazilian women with a positive family history are at high risk of being $B R C A 1 / 2$ carriers.

Li-Fraumeni syndrome is inherited in an autosomal dominant manner and is associated with germ line mutations in the TP53 gene. Despite the broad range of pathogenic mutations in this gene, a specific mutation occurring in the tetramerization domain of the TP53 gene (p.R337H) has been reported at a high prevalence 
in southern and southeastern Brazil. Recent studies have identified p.R377H carriers in a variety of tumors, in particular, early breast cancer [36]. In our analysis, the three carriers had breast cancer prior to the age of 50 without a family history of other tumors typical of LiFraumeni syndrome. Therefore, due to the high prevalence of the $\mathrm{R} 337 \mathrm{H}$ mutation in southeast Brazil, we asserted that a genetic test for this variant is strongly recommended for families matching clinical criteria for $\mathrm{HBOC}$ and in whom mutation testing for BRCA1 and $B R C A 2$ is negative.

Germ line DNA CNVs have recently been implicated in predisposition to different tumors [17]. In this regard, Rouleau and colleagues [37] used an in-house array CGH platform to search for copy number imbalances in ten genes involved in hereditary breast and ovarian cancer including BRCA1, BRCA2, CHEK2, BARD1, ATM, RAD50, RAD51, BRIP1, RAP80 and PALB2. In a series of 472 patients, they found only three large rearrangements in $B R C A 1 / 2$, two in CHEK2 and one intronic deletion in BRIP1. In our series, with the exception of RAP80, all genes were also evaluated for DNA copy number imbalances. We detected four large rearrangements (3\% of the cohort), thus confirming the two rearrangements affecting $B R C A 1$ and revealing two one-exon deletions in the ATM and PTEN genes. Since we cannot rule out the presence of point mutations in these 14 genes, we can only suggest that germ line CNVs in these genes are at low frequencies. Additionally, CNVs in both BRCA1 and BRCA2 genes were also confirmed to be at low frequency in this Brazilian HBOC series.

Germ line point mutations in ATM and PTEN have been reported to play a role in breast cancer predisposition [38-40]. However, to our knowledge, CNVs within these genes had never been reported in HBOC patients. In the current study, patient SM-46, who was found to carry an exon 4 deletion in the ATM gene, also had a pathogenic mutation in the $B R C A 2$ gene; therefore, the involvement of the ATM intragenic deletion with breast cancer predisposition in this particular case remains to be clarified.

Germ line mutations in the PTEN gene are associated with the PTEN hamartoma tumor syndrome (PHTS) in which Cowden syndrome (CS) is the most common phenotype. Patients with CS are at an increased risk of a variety of tumors including a $50 \%$ increased lifetime risk for breast cancer [41]. Although one of our BC patients presented a PTEN exon 2 deletion, recently, Sandell and colleagues described an 899-bp intronic deletion located 58 bp upstream PTEN exon 2 (c.80-956_-58del899), which was identified in $4 \%$ of British PHTS patients and in 3\% of healthy individuals [20]. Apparently, this British alteration is the same found in our $\mathrm{BC}$ patient; one of the primer pairs designed for duplex PCR was located within this polymorphic region. Nevertheless, according to Sandell and colleagues, the presence of this polymorphism in healthy individuals, the lack of aberrant splicing and the co-occurrence with known pathogenic mutations indicate that this variant is probably a polymorphism and has no phenotypic effect.

\section{Conclusions}

In summary, this is the most comprehensive $B R C A 1 / 2$ mutation screening study of Brazilian $\mathrm{BC}$ patients from families with hereditary breast and ovarian cancer. The study demonstrates a high prevalence of $B R C A 1$ point mutations and low frequency of CNVs within the BRCA1 and BRCA2 genes. Moreover, the detection of the TP53 $\mathrm{R} 337 \mathrm{H}$ variant in our series and the fact that this variant has a founder effect in our population prompted us to suggest that all female breast cancer patients with clinical criteria for $\mathrm{HBOC}$ and negative for BRCA1/2 genes should be tested for this variant. Additionally, the identification of CNVs in other breast cancer susceptibility genes revealed the complex genetic basis of this series of 120 unrelated Brazilian women with hereditary breast and ovarian cancer.

\section{Additional files}

Additional file 1: Complete molecular information of 120 patients.

Additional file 2: MLPA analysis. A. Electropherograms showing

reduced peaks (arrows) of exons 16 and 17 of the BRCA1 gene in patient

SM-03 compared with a control sample (C), characterizing a two-exon

deletion. B. Electropherogram obtained from the patient MO-28 showing

the amplification (off-scale peak) of exon 24 in the BRCA1 gene (arrow).

\section{Competing interests}

The authors declare that they have no competing interests.

\section{Authors' contributions}

BMR and DMC conceived the study; FCCS, BCL, MCPF, GT, ACK and DMC performed and analyzed the experiments. EMMS, MIA and BMR assessed the clinical data and selected patients. BMR and DMC contributed reagents, materials and analysis tools. FCS and DMC wrote and edited the manuscript. $\mathrm{BCL}, \mathrm{MCPF}$ and GTT edited and revised the manuscript. All authors have read and approved the final version of the manuscript.

\section{Acknowledgments}

The authors thank Dr. Ricardo R. Brentani (in memoriam), the patients and the A. C. Camargo biobank, specially the DNA and RNA bank.

\section{Grant support}

Brazilian Federal Agency Conselho Nacional de Desenvolvimento Científico e Tecnológico (408833/2006-8) and Fundação de Amparo à Pesquisa do Estado de São Paulo (2008/57887-9).

\section{Author details}

${ }^{1}$ Laboratory of Genomics and Molecular Biology, CIPE - A. C. Camargo Cancer Center, São Paulo, Brazil. '2Department of Colorectal Tumors, A. C. Camargo Cancer Center, São Paulo, Brazil. ${ }^{3}$ National Institute of Science and Technology in Oncogenomics (INCITO), São Paulo, Brazil. ${ }^{4}$ Department of Oncogenetics, A. C. Camargo Cancer Center, São Paulo, Brazil.

Received: 17 December 2013 Accepted: 29 April 2014 Published: 15 May 2014 


\section{References}

1. Clark AS, Domchek SM: Clinical management of hereditary breast cancer syndromes. J Mammary Gland Biol and Neoplasia 2011, 16(1):17-25.

2. Durocher F, Tonin P, Shattuck-Eidens D, Skolnick M, Narod SA, Simard J: Mutation analysis of the BRCA1 gene in 23 families with cases of cancer of the breast, ovary, and multiple other sites. J Med Genet 1996, 33:814-819.

3. Ford D, Easton DF, Bishop DT, Narod SA, Goldgar DE: Risks of cancer in BRCA1-mutation carriers. Breast Cancer Linkage Consortium. Lancet 1994, 343:692-695.

4. Ford D, Easton DF, Stratton M, Narod S, Goldgar D, Devilee P, Bishop DT, Weber B, Lenoir G, Chang-Claude J, Sobol H, Teare MD, Struewing J, Arason A, Scherneck S, Peto J, Rebbeck TR, Tonin P, Neuhausen S, Barkardottir R, Eyfjord J, Lynch H, Ponder BA, Gayther SA, Zelada-Hedman M, and the Breast Cancer Linkage Consortium: Genetic heterogeneity and penetrance analysis of the BRCA1 and BRCA2 genes in breast cancer families. the Breast Cancer Linkage Consortium. Am J Hum Genet 1998, 62(3):676-689.

5. Thorlacius S, Olafsdottir G, Tryggvadottir L, Neuhausen S, Jonasson JG, Tavtigian SV, Tulinius H, Ogmundsdottir HM, Eyfjörd JE: A single BRCA2 mutation in male and female breast cancer families from Iceland with varied cancer phenotypes. Nat Genet 1996, 13(1):117-119.

6. Tonin PN, Mes-Masson AM, Futreal PA, Morgan K, Mahon M, Foulkes WD, Cole DE, Provencher D, Ghadirian P, Narod SA: Founder BRCA1 and BRCA2 mutations in French Canadian breast and ovarian cancer families. Am J Hum Genet 1998, 63(5):134113-134151.

7. Peto J, Collins N, Barfoot R, Seal S, Warren W, Rahman N, Easton DF, Evans C, Deacon J, Stratton MR: Prevalence of BRCA1 and BRCA2 gene mutations in patients with early-onset breast cancer. J Natl Cancer Inst 1999, 91:943-949.

8. Schutte M, Seal S, Barfoot R, Meijers-Heijboer H, Wasielewski M, Evans DG, Eccles D, Meijers C, Lohman F, Klijn J, van den Ouweland A, Futreal PA, Nathanson KL, Weber BL, Easton DF, Stratton MR, Rahman N, Breast Cancer Linkage Consortium: Variants in CHEK2 other than 1100delC do not make a major contribution to breast cancer susceptibility. Am J Hum Genet 2003, 72(4):1023-1028.

9. Meijers-Heijboer H, van den Ouweland A, Klijn J, Wasielewski M, de Snoo A, Oldenburg R, Hollestelle A, Houben M, Crepin E, van Veghel-Plandsoen M, Elstrodt F, van Duijn C, Bartels C, Meijers C, Schutte M, McGuffog L, Thompson D, Easton D, Sodha N, Seal S, Barfoot R, Mangion J, Chang-Claude J, Eccles D, Eeles R, Evans DG, Houlston R, Murday V, Narod S, Peretz T, Peto J, Phelan C, Zhang HX, Szabo C, Devilee P, Goldgar D, Futreal PA, Nathanson KL, Weber B, Rahman N, Stratton MR, CHEK2-Breast Cancer Consortium: Low-penetrance susceptibility to breast cancer due to CHEK2 $\left.2^{*}\right) 1100 \mathrm{delC}$ in noncarriers of BRCA1 or BRCA2 mutations. Nat Genet 2002, 31:55-59.

10. CHEK2 Breast Cancer Case-control Consortium: CHEK2*1100delC and susceptibility to breast cancer: a collaborative analysis involving 10,860 breast cancer cases and 9,065 controls from 10 studies. Am J Hum Genet 2004, 74:1175-1182.

11. Achatz MI, Hainaut P, Ashton-Prolla P: Highly prevalent TP53 mutation predisposing to many cancers in the Brazilian population: a case for newborn screening? Lancet Oncol 2009, 10(9):920-925.

12. Plevritis SK, Kurian AW, Sigal BM, Daniel BL, Ikeda DM, Stockdale FE, Garber AM: Cost-effectiveness of screening BRCA1/2 mutation carriers with breast magneticresonance imaging. JAMA 2006, 295(20):2374-2384.

13. Farmer H, McCabe N, Lord CJ, Tutt AN, Johnson DA, Richardson TB, Santarosa M, Dillon KJ, Hickson I, Knights C, Martin NM, Jackson SP, Smith GC, Ashworth A: Targeting the DNA repair defect in BRCA mutant cells as a therapeutic strategy. Nature 2005, 434(7035):917-921. 14

14. Breast Cancer Information Core. [http://research.nhgri.nih.gov/bic/]

15. Vallée MP, Francy TC, Judkins MK, Babikyan D, Lesueur F, Gammon A, Goldgar DE, Couch FJ, Tavtigian SV: Classification of missense substitutions in the BRCA genes: a database dedicated to Ex-UVs. Hum Mutat 2012, 33(1):22-28.

16. Sorting Intolerant From Tolerant. [http://sift.jcvi.org/www/SIFT_BLink_ submit.html]

17. Polyphen-2. [http://genetics.bwh.harvard.edu/pph2/]

18. Align GVGD. [http://agvgd.iarc.fr/agvgd_input.php]

19. Krepischi AC, Achatz Ml, Santos EM, Costa SS, Lisboa BC, Brentani H, Santos TM, Gonçalves A, Nóbrega AF, Pearson PL, Vianna-Morgante AM, Carraro DM, Brentani RR, Rosenberg C: Germline DNA copy number variation in familial and early-onset breast cancer. Breast Cancer Res 2012, 14(1):R24.
20. Torrezan GT, da Silva FC C, Krepischi AC, Monteiro Dos Santos EM, Rossi BM, Carraro DM: A novel SYBR-based duplex qPCR for the detection of gene dosage: detection of an APC large deletion in a familial adenomatous polyposis patient with an unusual phenotype. BMC Med Genet 2012 13:55

21. Sandell S, Schuit RJ, Bunyan DJ: An intronic polymorphic deletion in the PTEN gene: implications for molecular diagnostic testing. Br J Cancer 2013, 108(2):438-441. 201.

22. Dufloth RM, Carvalho S, Heinrich JK, Shinzato JY, dos Santos CC, Zeferino LC, Schmitt F: Analysis of BRCA1 and BRCA2 mutations in Brazilian breast cancer patients with positive family history. Sao Paulo Med J 2005, 123(4):192-197.

23. da Costa EC, Vargas FR, Moreira AS, Lourenço JJ, Caleffi M, Ashton-Prolla P, Martins Moreira M: Founder effect of the BRCA1 5382insC mutation in Brazilian patients with hereditary breast ovary cancer syndrome. Cancer Genet Cytogenet 2008, 184(1):62-66.

24. Esteves VF, Thuler LC, Amêndola LC, Koifman RJ, Koifman S, Frankel PP, Vieira RJ, Brazilian Network of Breast and Ovarian Familial Cancer Aggregation: Prevalence of BRCA1 and BRCA2 gene mutations in families with medium and high risk of breast and ovarian cancer in Brazil. Braz J Med Biol Res 2009, 42(5):453-457.

25. Ewald IP, Izetti P, Vargas FR, Moreira MA, Moreira AS, Moreira-Filho CA, Cunha DR, Hamaguchi S, Camey SA, Schmidt A, Caleffi M, Koehler-Santos P, Giugliani R, Ashton-Prolla P: Prevalence of BRCA1 and BRCA2 mutations in breast cancer patients from Brazil. Breast Cancer Res Treat 2007, 103:349e53

26. Ewald IP, Izetti P, Vargas FR, Moreira MA, Moreira AS, Moreira-Filho CA, Cunha DR, Hamaguchi S, Camey SA, Schmidt A, Caleffi M, Koehler-Santos P, Giugliani $R$, Ashton-Prolla P: Prevalence of the BRCA1 founder mutation c.5266dupin Brazilian individuals at-risk for the hereditary breast and ovarian cancer syndrome. Hered Cancer Clin Pract 2011, 20(9):12.

27. Lourenco JJ, Vargas FR, Bines J, Santos EM, Lasmar CAP, Costa CH, Texeira EMB, Maia MCM, Coura F, Silva CHD, Moreira MAM: BRCA1 mutations in Brazilian patients. Genet Mol Biol 2004, 27:500e4.

28. Carraro DM, Koike Folgueira MA, Garcia Lisboa BC, Ribeiro Olivieri EH, Vitorino Krepischi AC, de Carvalho AF, de Carvalho Mota LD, Puga RD, do Socorro Maciel M, Michelli RA, de Lyra EC, Grosso SH, Soares FA, de Souza Waddington Achatz MI, Brentani H, Moreira-Filho CA, Brentani MM: Comprehensive analysis of BRCA1, BRCA2 and TP53 germline mutation and tumor characterization: a portrait of early-onset breast cancer in Brazil. Plos One 2013, 8(3):e57581. 201.

29. Loman N, Johannsson O, Kristoffersson U, Olsson H, Borg A: Family history of breast and ovarian cancers and BRCA1 and BRCA2 mutations in a population-based series of early-onset breast cancer. J Natl Cancer Inst 2001, 93(16):1215-1223.

30. Meindl A, German Consortium for Hereditary Breast and Ovarian Cancer: Comprehensive analysis of 989 patients with breast or ovarian cancer provides BRCA1 and BRCA2 mutation profiles and frequencies for the German population. Int I Cancer 2002, 97(4):472-480.

31. Nanda R, Schumm LP, Cummings S, Fackenthal JD, Sveen L, Ademuyiwa F, Cobleigh M, Esserman L, Lindor NM, Neuhausen SL, Olopade Ol: Genetic testing in an ethnically diverse cohort of high-risk women: a comparative analysis of BRCA1 and BRCA2 mutations in American families of European and African ancestry. JAMA 2005, 294(15):1925-1933.

32. Finkelman BS, Rubinstein WS, Friedman S, Friebel TM, Dubitsky S, Schonberger NS, Shoretz R, Singer CF, Blum JL, Tung N, Olopade Ol, Weitzel JN, Lynch HT, Snyder C, Garber JE, Schildkraut J, Daly MB, Isaacs C, Pichert G, Neuhausen SL, Couch FJ, van't Veer L, Eeles R, Bancroft E, Evans DG, Ganz PA, Tomlinson GE, Narod SA, Matloff E, Domchek S, et al: Breast and Ovarian Cancer Risk and Risk Reduction in Jewish BRCA1/2 Mutation Carriers. J Clin Oncol 2012, 30(12):1321-1328.

33. Hamel N, Feng BJ, Foretova L, Stoppa-Lyonnet D, Narod SA, Imyanitov E, Sinilnikova O, Tihomirova L, Lubinski J, Gronwald J, Gorski B, Hansen T, Nielsen FC, Thomassen M, Yannoukakos D, Konstantopoulou I, Zajac V, Ciernikova S, Couch FJ, Greenwood CM, Goldgar DE, Foulkes WD: On the origin and diffusion of BRCA1 c.5266dupC (5382insC) in European populations. Eur J Hum Genet 2011, 19(3):300-306.

34. Pagenstecher $C$, Wehner M, Friedl W: Aberrant splicing in MLH1 and MSH2 due to exonic and intronic variants. Hum Genet 2006, 119(1-2):9-22.

35. Caputo S, Benboudjema L, Sinilnikova O, Rouleau E, Béroud C, Lidereau R, French BRCA GGC Consortium: Description and analysis of genetic 
variants in French hereditary breast and ovarian cancer families recorded in the UMD BRCA1/BRCA2 databases. Nucleic Acids Res 2012, 40(Database issue):D992-D1002.

36. Palmero El(1), Schüler-Faccini L, Caleffi M, Achatz Ml, Olivier M, Martel-Planche G, Marcel V, Aguiar E, Giacomazzi J, Ewald IP, Giugliani R, Hainaut $\mathrm{P}$, Ashton-Prolla P: Detection of $\mathrm{R} 337 \mathrm{H}$, a germline TP53 mutation predisposing to multiple cancers, in asymptomatic women participating in a breast cancer screening program in Southern Brazil. Cancer Lett 2008, 261(1):21-25.

37. Rouleau E, Jesson B, Briaux A, Nogues C, Chabaud V, Demange L, Sokolowska J, Coulet F, Barouk-Simonet E, Bignon YJ, Bonnet F, Bourdon V, Bronner M, Caputo S, Castera L, Delnatte C, Delvincourt C, Fournier J, Hardouin A, Muller D, Peyrat JP, Toulas C, Uhrhammer N, Vidal V, Stoppa-Lyonnet D, Bieche I, Lidereau R: Rare germline large rearrangements in the BRCA1/2 genes and eight candidate genes in 472 patients with breast cancer predisposition. Breast Cancer Res Treat 2012, 133(3):1179-1190.

38. Walsh T, King MC: Ten genes for inherited breast cancer. Cancer Cell 2007, 11(2):103-105

39. Bell DW, Varley JM, Szydlo TE, Kang DH, Wahrer DC, Shannon KE, Lubratovich M, Verselis SJ, Isselbacher KJ, Fraumeni JF, Birch JM, Li FP, Garber JE, Haber DA: Heterozygous germline hCHK2 mutations in Li-Fraumeni syndrome. Science 1999, 286:2528-2531.

40. The Cancer Genome Atlas Network: Comprehensive molecular portraits of human breast tumours. Nature. 2012, 490(7418):61-70.

41. Nusbaum R, Vogel KJ, Ready K: Susceptibility to breast cancer: hereditary syndromes and low penetrance genes. Breast Dis 2006, 27:21-50.

doi:10.1186/1471-2350-15-55

Cite this article as: Silva et al: Hereditary breast and ovarian cancer: assessment of point mutations and copy number variations in Brazilian patients. BMC Medical Genetics 2014 15:55.

\section{Submit your next manuscript to BioMed Central and take full advantage of:}

- Convenient online submission

- Thorough peer review

- No space constraints or color figure charges

- Immediate publication on acceptance

- Inclusion in PubMed, CAS, Scopus and Google Scholar

- Research which is freely available for redistribution 